University of Nebraska - Lincoln

DigitalCommons@University of Nebraska - Lincoln

Copyright, Fair Use, Scholarly Communication, etc.

9-2017

Information in the ecosystem: Against the "information ecosystem"

Timothy B. Norris

Todd Suomela

Follow this and additional works at: https://digitalcommons.unl.edu/scholcom

Part of the Intellectual Property Law Commons, Scholarly Communication Commons, and the Scholarly Publishing Commons

This Article is brought to you for free and open access by the Libraries at University of Nebraska-Lincoln at DigitalCommons@University of Nebraska - Lincoln. It has been accepted for inclusion in Copyright, Fair Use, Scholarly Communication, etc. by an authorized administrator of DigitalCommons@University of Nebraska Lincoln. 


\title{
$f \mathbf{i}$ (3) $s+m \boldsymbol{x} \tilde{\mathbf{n}} \mathbf{d} @ \mathbf{z}$
}

PEER-REVIEWED JOURNAL ON THE INTERNET

\section{Information in the ecosystem: Against the "information ecosystem" by Timothy B. Norris and Todd Suomela}

\begin{abstract}
The "information ecosystem" metaphor is widely used in academic libraries and has become nearly ubiquitous when speaking of the information systems that support scholarly communication and varied forms of data sharing and publication. The trending use of this language arises from non-academic applications - for example in big data (the Hadoop ecosystem) or software development (the node.js ecosystem) — and there remains little critical examination of the use of this metaphor. Indeed, the definition of ecosystem as the set of relations between living organisms and their surrounding non-living environment is apparently not directly a part of the metaphor. This paper first describes the emergence of ecological thinking and how it was influenced by early information science and then explores how different "ecologies" are used within the academy, including in the emergent field of information ecology. A short critique of the metaphor is then posed and the paper concludes that the information ecosystem metaphor is useful, yet at the same time there are dangerous elements that render aspects of human societies and natural ecosystems invisible.
\end{abstract}

\section{Contents}

1. Introduction

2. Background: Ecology and ecosystems

3. Adjacent ideas and ecological adoptions

4. Two programs for information ecology

5. Critique of the "information ecosystem"

$\underline{\text { 6. Conclusions }}$

\section{(c) (7) (8)}

4.0 International License.

First Monday, Volume 22, Number 9 - 4 September 2017

https://firstmonday.org/ojs/index.php/fm/article/download/6847/6530 


\section{Introduction}

For the right use of metaphor means an eye for resemblances. Aristotle, Poetics [1]

The use of metaphor is arguably one of the more powerful learning devices to better understand novel phenomena (Livingstone and Harrison, 1981; Anderson, 2016). Consider the influence of Descartes' animal bodies as machines made of earth (Abram, 1991) or the controversy that surrounds the suggestion that the Earth is an auto-poietic system from the Gaia Hypothesis (Lovelock and Margulis, 1974). In a similar context of machines and organisms, an "information ecosystem" metaphor is widely used in academic libraries and has become nearly ubiquitous when speaking of the information systems that support scholarly communication and varied forms of data sharing and publication [2].

The use of ecosystem metaphors in the context of academic libraries and scholarly communication likely reflects the influence of Ranganathan's famously suggested five laws of librarianship; the final law states that the Library is a growing organism. Organismic metaphors were popular at the time he was writing so we should not be surprised that for Ranganathan (1931) the library is literally alive, encompassing notions of growth, evolution, a touch of diversity, and some vitality.

Moving from organism to ecosystem is almost a "natural" development of this metaphor. Today, the rhetoric of information is found in both academic and non-academic contexts. For example, the "Hadoop ecosystem" (cluster based storage for big data), the "Node.js ecosystem" (software development), and industry conference titles such as "International Conference on Digital Ecosystems and Technologies." The use of this metaphor is part of a widespread "everyday vernacular where it's [the information ecosystem] about a large network of interconnected practices" that exist both within the information technology industry and the hard- to- describe information systems-society entanglement [3].

While it is easy to use readily understandable language to inform thinking on this novel entanglement, the definition of the ecosystem as a community of living organisms - plants, animals, fungi, and so on - and the set of relations with their surrounding non-living environment, is apparently not a part of the academic use of the metaphor or the vernacular use of the term. Furthermore, it is possible that the current popularity of the "information ecosystem" metaphor is an ill-planned outcome of (un)intentional efforts in the 1990s to green the information economy. Indeed, there is little critical examination of how the metaphor is used (although see Stepp, 1999; Nowviskie, 2014; Norris, 2014).

The "information ecosystem" metaphor is both powerful and useful, nevertheless. Information systems - perhaps better named "data assemblages" (Kitchin, 2014), "digitally constructed memories" or "cross-domain knowledge bases" (Baker and Bowker, 2007) — under development within institutions of research and education are like ecosystems in many ways. They contain diversity in human actors, institutions, norms and practices, and there is enormous 
diversity within the data, metadata, and information itself. The systems are vast interconnected networks comprised of hierarchical levels in which technological and human actors play specific roles. Furthermore, a system that can use "humans as sensors takes on an organic, hybrid, ecological quality." [4] There are serious questions about sustainability, albeit mostly economic, of information systems similar to those of natural ecosystems. What do we sustain, for who, and at what cost (cf., Merenlender, et al., 2004; Liverman, 2004; Kitchin, 2014)?

There are limiting resources that govern the growth and evolution of the information systems including human and financial resources, material resources like spinning disks, and the information itself. We can observe dynamic equilibriums of stocks and flows in these information systems that are perhaps governed by the limiting factors above and ever-shifting interpretations of intellectual property law (for example, see Yu, 2005). Predator-prey relationships, such as those between publishers and authors, can be observed where lively competition takes place for the consumption and production of information resources. In a similar vein thriving cooperative communities are built on shared needs for survival. Perhaps there are even emergent properties in the "information ecosystem" either akin to artificial intelligence arising from well-formed linked open data, or simply a system so complex that no one person can understand its entirety. Indeed, the "information ecosystem" is an unknowable whole that is greater than the sum of its parts. It evolves and grows in an almost lifelike fashion. It is an autopoietic system like Gaia.

This last example likely stretches the metaphor beyond its useful limits, but with purpose. This paper interrogates the usefulness and limits of this broadly used metaphor by asking such questions as what are the similarities between a data assemblage and an ecosystem? How can elemental cycles, flows of energy, and information exchange be conceptualized through the metaphor? How can the idea of contextualized communities, both human and non-human, be better expressed? And finally, are there shared characteristics of sustainable resource governance in ecosystem management and the management of data?

Through an explicit exploration of the ecology literature the paper provides an initial attempt to articulate a link between the robust literature about data within geography and the literature in library and information science about the same topic. Our hope is that this interdisciplinary engagement will contribute to the emergent fields of information and cognitive ecologies and provide more productive ways to understand novel roles of data in socio-natural systems. It also provides a platform to critique the metaphor, particularly how it is used in the context of scholarly communication.

The essay begins with a short history of ecological thinking, both in the academy and popular culture. This is followed by an exploration of how "information ecology" as a term emerged in the 1970s from systems management and anthropological literatures. The adoption of ecological concepts into social science in the 1980s and 1990s is then explored through four examples from human ecology, cognitive ecology, media ecology, and political ecology. Next, two programs for "information ecology" from business management literature are examined. A critique of how the metaphor is used follows, with a focus on its use in information science and scholarly communication literature. The paper concludes that the "information ecology" metaphor helps us grapple with the novel entanglements between information systems and human societies, but it 
may also pose several dangers, including the marginalization of morality in human communities and the disappearance of nature itself.

\section{Background: Ecology and ecosystems}

The credit for coining the word "ökologie" is generally given to Ernst Haeckel (1866) who suggested that this term should refer to the study of nature's economy. This does not suggest that ecological thinking has a history of only 160 years. Haeckel likely drew from Linnaeus' eighteenth century conception of the "economy of nature" (Worster, 1994). Furthermore, if we consider a modern definition of ecology as "... the study of the structure and function of nature, it being understood that mankind is a part of nature" we can trace the lineage of ecological thought back to classical Greece [5] .

Nevertheless, the term ecosystem was introduced much more recently in 1935 by Arthur Tansley, an ecologist frustrated with the use of organismic metaphors to describe biotic communities and their environs (see Figure 1). This frustration also extended to applying the organismic metaphor to "human communities as habitually so constituted." His goal in coining the term was to clarify the notion that the "ecosystem" is an abstraction of climate, Earth, and life that does not exist outside of human thought (Tansley, 1935). An ecosystem is understood as a community of living organisms - the biocoenosis: plants, animals, fungi, and so on - and the set of relationships between organisms and with their surrounding non-living environment — the biotope (Tansley, 1935; Odum, 1971). Living communities, natural environs, and relationships all together form - ecosystems.

To confuse matters, the term ecology has recently come to refer to simply the relationships found in an ecosystem (Oxford English Dictionary, 2008). One of the difficulties with the information ecosystem metaphor is this confusion of ecologies with ecosystems. For purposes of clarity in this essay the term(s) ecology(ies) will be used in the original sense to refer to the study(ies) of ecosystems - unless explicitly noted otherwise — not the communities and sets of relations found within an ecosystem.

\subsection{Early ecosystem thinking and evolution}

Evolution, competition, and cooperation have been applied to ecosystem thinking since its inception, although not without difficulties and ideological differences. As originally conceived by Darwin, evolution was largely competitive; individuals from certain species were in constant struggle to claim and maintain their places — or ecological niches — in nature's economy. His theory of "descent with modification" was developed in the context of Malthusian thinking on human populations in which food resources increase in a linear fashion and population grows in an exponential manner so that competitive survival quickly becomes "red in tooth and claw" not only between species, but within the same species (Stoddart, 1966; Tennyson, 1849) [్] . 
Darwin's idea of competitive evolution was quickly adopted to explain phenomena in human societies. The idea of "the survival of the fittest" was applied to relations between humans and between humans and the environment. Darwin did not intend for evolutionary metaphors to be used in these contexts and the results were, and continue to be, problematic. The application to human relations produced dire consequences such as Hitler's adoption of the notion of lebensraum - in which political nation-states are said to "evolve" and claim spaces in the global economy — to justify his campaign to exterminate Jews [7]. The application to humanenvironment relations produced rhetoric which claimed it is our human destiny to control and dominate nature (Stoddart, 1966; Worster, 1994).

What was overlooked is that notions of competition do not preclude ideas of symbiosis or mutualism in the evolution of species. At the turn of the twentieth century there were thinkers such as Hermann Reinheimer, Petr Kropotkin, and Eugenius Warming who attempted to highlight cooperation and symbiosis as essential strategies for survival in the competitive world (Worster, 1994). For example, Kropotkin's (1987) work emphasized the cooperative aspects of evolution in both biological and human communities. His thesis leads led to current explanations of mutualism in which species co-evolve and rely on one another to survive.

These thinkers all used the Linnaeus' economy of nature metaphor to include human economic organization in ecological explanations. The self-reliant competitor is but a romanticized idea borrowed from frontier ideologies; thus natural communities reflect human communities in which cooperation is the norm, not competition (Worster, 1994). The economy of nature metaphor was also instilled in the work of the later reductionists and ecology took on the appearance of a subordinate field of economics and econometrics. In a non-intuitive turn, the ecosystem was understood as a mirror of human economic production and consumption (see section 2.2).

With this brief history in mind, should we be more explicit in how ecosystem and economy come together in the information ecosystem metaphor? For example, is the information ecosystem driven by competition, cooperation, or some blend of both? If so, who is competing and cooperating? Should we be concerned with unjust ethics based on the survival of the fittest? Might inattention to this question lead to forms of digital racism where those without data are lesser humans or where the status quo control of data reinforces existing forms of racism?

\subsection{The quantitative revolution: Holism and reductionism}

As the nascent field of ecology entered into the post WWII quantitative revolution, ecologists claimed an identity as data driven scientists. The arguments that pitted holism vs. reductionism and organismic vs. mechanistic explanations of nature were central to the debates on the definition of the field and the work of the ecologist (Barbour, 1995). A key proponent of the holistic approach was Frederick Clements, who claimed that ecosystems were wholes that were greater than the sums of their parts. He also claimed that entire ecosystems "evolved" along an observable succession of steps to maturity. Thus, a given combination of soil, climate, and organisms will always proceed to a defined stable endpoint (Clements, 1936). 
Henry Gleason (1939), on the other hand, promoted the view that there is no ecosystem and that all "plant associations" (his term for plant communities or ecosystems) are made of individuals competing for resources and space. Gleason also paid close attention to the problem of scale in ecology and how the scale of analysis determines how an observing scientist will classify an association of plants. Ecologists still profess four main scales in ecology: organism, population, community, and landscape (Odum, 1971).

Clements' view led to a (non-quantifiable) holistic approach and that of Gleason led to a (quantifiable) reductionist approach (Barbour, 1995; Worster, 1994). With the post-war preference for quantitative work in scientific funding agencies, the reductionist approach gained the most currency; ecology began to be identified as a hard science. By the end of the 1960s the emphasis on quantification led to a "new ecology" in which the principal object of study was the flow of energy and nutrients through the ecosystem (Worster, 1994; Barbour, 1995).

The nature as machine metaphor had won out over the nature as organism metaphor (Hagen, 1992). Yet as prominent ecologist C.S. Holling recently observes, the analytical [reductionist] approach tends to come up with "exactly the right answer to the wrong question" while the integrative [holistic] approach asks "exactly the right question but [produces a] useless answer." [8] From another perspective John Cantlon explains that "The individualistic community [reductionist] is likely to remain the more useful paradigm for most work understanding ecosystem processes. However ... for landscape interpretation and management purposes, we will undoubtedly continue to the ... taxonomic community [holistic].” [9]

This debate continues in ecology and it is articulated with similar debates in the academy at large. There is a constant tension between holistic and reductionist epistemological approaches to understanding how parts function and understanding how wholes function. At the extreme poles of this debate, some claim that "everything is connected to everything" (Commoner, 1971) while others claim that a particular cause leads to a specific effect.

This tension between holism and reductionism is readily apparent in the information ecosystem understood as an assemblage of machines, data, code, and human operators all functioning within economies governed by local and global policies. The question of whether it should it be understood as a collection of mechanistic and quantifiable parts or if it should it be understood as a whole that is greater than the sum of its parts is still arduously debated. Or perhaps both approaches are useful depending on the argument to be made?

\subsection{Ecology and the environmental movement}

"Ecology" and "ecosystem" have become important parts of the English language and are considered household terms in addition to the more academic uses outlined earlier (see Figure 1). In addition to deepening our understandings of natural processes, ecologists have also given rise to an environmental ethic. The writings of Aldo Leopold (1949), Rachel Carson (1962), Paul Ehrlich (1968), and Barry Commoner (1971) are often cited as influential in initiating the environmental movement of the 1970s. Today we recognize the shortcomings of their work but these researchers contributed to the idea of the academic activist in the realm of protecting and conserving the natural environment. 


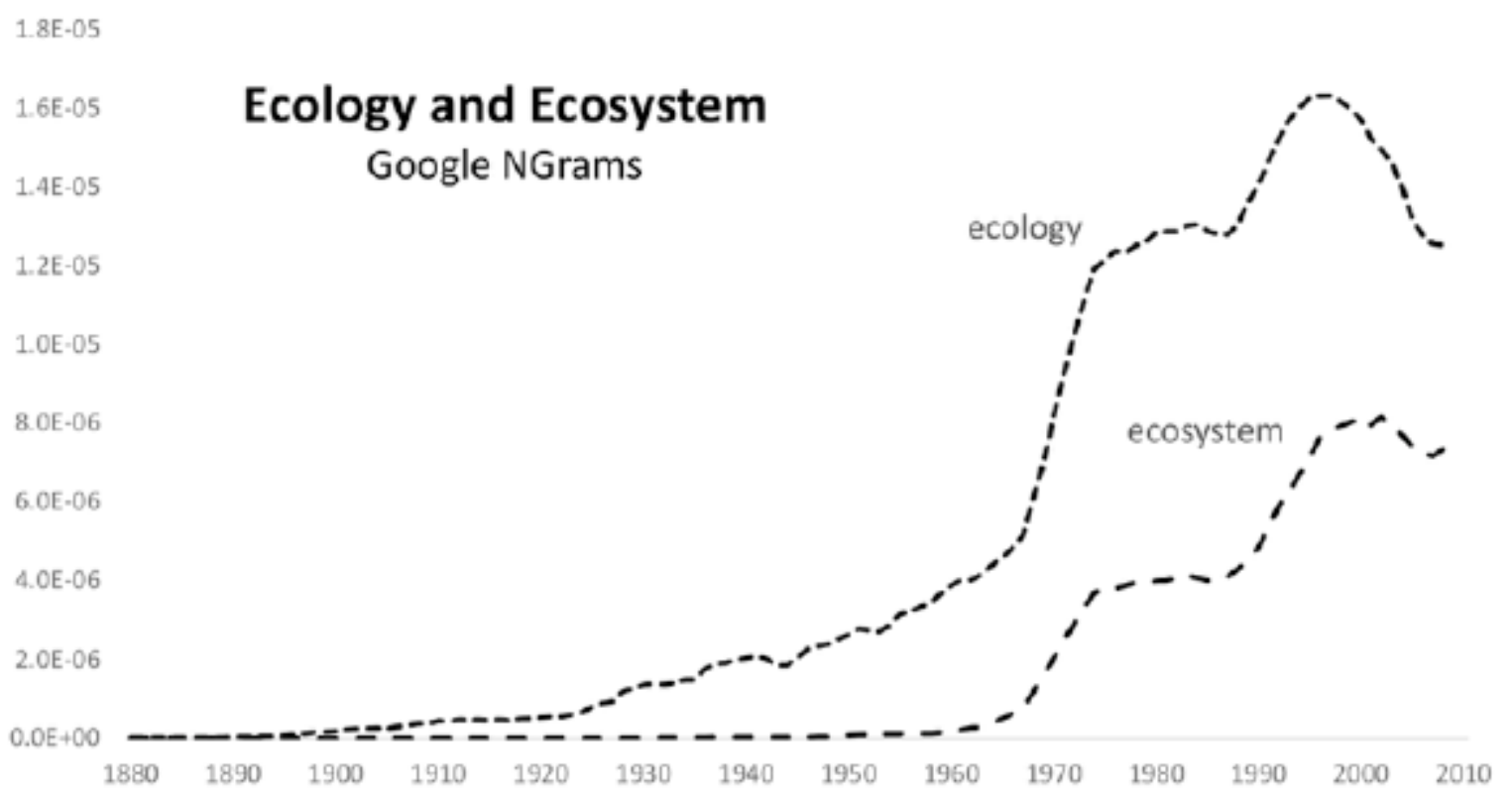

Figure 1: The emergent use of the words "ecology" and "ecosystem" as a Google Ngram. The rise in the 1970s is attributable to the first Earth Day (on 22 April 1970) and the birth of the environmental movement. The second rise in the 1990s can be attributed to broader use of ecological metaphors outside of ecology (see Figure 2).

As writers, they were also fundamental in promoting two key principles in the environmental movement. First, that man is a part of nature and not outside of or above natural law. Leopold stated clearly that "The land ethic ... simply enlarges the boundaries of the [human] community to include soils, waters, plants, and animals, or collectively the land." [10] Second, there may be planetary limits to economic growth. One of the key pieces of literature, the Club of Rome Report, or The Limits to Growth, is based on a computer model of population and resources at a planetary scale (Meadows, et al., 1972). It represents an early and important intersection of data science, computational models, global ecology, and sustainable resource management.

In this managerial vein the information ecosystem metaphor resonates powerfully with ecological thinking. Does the management of the information ecosystem imply the (white male) domination of the system as it often does with the management of nature in Western cultures (notably also where the information ecosystem might be located; see also section 2.1)? Or do we seek to manage information ecosystems from a Leopoldian perspective of a more than human community? If so, what other living actors should we consider as members of this community? Do we see the information ecosystem as limited by certain resources? Is the information ecosystem linked to the global ecosystem? 


\subsection{Ecology and conservation management}

In conservation management sustainability is directly related to stability. As examples, the roles of competition, cooperation, synergism, and co-dependency in ecology are all factors that influence stability and thus the sustainability of particular ecosystems. Each factor is explored briefly below.

First, a limiting resource, such as nitrogen (food) or light (energy), may govern the behavior of the system, especially if competition for the resource exists. The "carrying capacity" of an ecosystem can be calculated based on such limiting resources. This simple calculation is very seductive yet it hides several dangers. Due to vagaries of the weather, natural and non-natural disturbances, and other factors, it is nearly impossible to calculate an accurate carrying capacity across time. Furthermore, when the calculation is applied to human populations, "lifeboat ethics" come into play. Instead of seeking political solutions to manage resources, the only solution is to limit human reproduction. Hard questions immediately arise as to who lives and who dies.

Second, ecosystem structure and function is thought to be sustained by "keystone species" which, if removed from the living community, may cause the ecosystem to spiral toward a different dynamic equilibrium. By definition the keystone species has one or more cooperative or synergistic relations with other organisms in the environment. The removal causes a trophic cascade - a catastrophic breakdown of the flows of energy and matter in the ecosystem. Humans cannot be considered as a keystone species, as in most cases their removal from an ecosystem does not cause a catastrophic breakdown of ecosystem structure and function.

Third, predator-prey populations have a co-dependent relationship where cause and effect are bidirectional. Once again humans cannot be considered predator nor prey for management reasons. It could imply either the encouragement of breeding or the culling of human populations, that latter of which is unthinkable.

These three ideas represent well-worn tools in conservation management, whether used to calculate the optimum number of ruminants for grazing an area of land, to protect keystone species through legislation, or to restore once decimated predator populations to control a prey population.

For a sustainable information ecosystem is it possible to borrow from the conceptual tools of conservation management? Are there limiting resources in an information ecosystem? Energy (particularly for cooling)? Financial resources? Who is competing for these resources? Why? Who wins and who loses? Are there "information ecologists" who are key actors in the sustainable management of digital resources? Could these people be considered keystone species in an information ecosystem? Are there predator-prey relationships in an information ecosystem? If so, who are the predators and the prey? Should these "populations" be managed for stability and sustainability?

\subsection{Dynamic equilibria and chaos theory}


In early ecological thinking the ecosystem evolved through several stages to reach a final stable state (section 2.2). This concept of an "evolved" ecosystem influenced conservation management by linking stability (the evolved endpoint) to sustainability (the long-term viability of the ecosystem). In current ecological thought this theory is debunked and instead "dynamic equilibriums" are used to describe states to which ecosystems tend to gravitate toward. This has profound implications for environmental managers that are not yet well understood [11].

C.S. Holling's (1973) twin concepts of systemic resistance to change and the resilience of a system after a major disturbance are often used to explain dynamic equilibriums in ecosystems. When observing populations of organisms that either compete for knowable quantities of resources (plant communities) or are in predator-prey relationships (animal communities) the demographics tend to hover around a stable point unless there is a disturbance (fire, weather event, human intervention).

Robert May (1974) questioned the idea of stable points in population dynamics and introduced the possibility of using chaotic models to explain observed population phenomena in ecosystems [12]. He demonstrated that with sufficient disturbance the model may gravitate to more than one stable point similar to strange attractors in chaos theory, or the system may bifurcate and enter periods of instability.

This approach drew heavily from cybernetic systems theory, especially the notion of the selfgoverning system comprised of negative and positive feedback loops that led to emergent properties of the system in question. The cybernetic-mechanistic approach in ecology led to complexity theory and finally back to holistic approaches to describe ecosystems as unknowable wholes (Barbour, 1995).

It is striking that even after the idea of the evolved stable ecosystem was laid to rest, many ecologists still seek stability in natural ecosystems as a form of sustainable management. While there is a popular belief that biodiversity begets stability through increased resistance and resilience to systemic disturbance, the evidence is split. In artificially closed study systems through choice of scale or boundaries - diversity may beget stability, yet in open systems concepts of thresholds, chaos, and tipping points may be more useful (for opposing arguments, see Tilman and Downing, 1994; Goodman, 1975). Furthermore, Joseph Connell (1978) proposed the still relevant thesis that the highest rates of biodiversity are maintained with intermediate rates of disturbance that imply non-stable ecosystem dynamics.

Yet most interventions to conserve and maintain biodiversity involve setting land aside and minimizing disturbance. An alternative proposal is found in the Panarchy literature in which humans and human organizations are explicitly considered as parts of an ecosystem. Holling's (1973) ideas of resistance and resilience are then applied to these broad socio-natural systems to make not only recommendations for ecological interventions that include moderate disturbance regimes (controlled burns, for example), but also to make recommendations for political interventions (Gunderson and Holling, 2002). "Adaptive management" is promoted in order to improve both social and environmental outcomes of planned interventions (Holling, 1978; Leopold, et al., 1963). Iterations through cycles of planning, action, evaluation and plan 
modification form part of an ongoing process in which the human role is emphasized in the sustainable management of ecosystems (Berkes, et al., 2000; Gunderson and Holling, 2002).

In the context of the information ecosystem, might these theories imply emergent properties in the information-society entanglement? It is likely that computers are unknowable wholes (there is no one person who understands everything about one computer). Does this imply that systems of computers are also beyond our understanding? Could the information ecosystem harbor intelligence? Does the configuration of the information ecosystem hover around strange attractors? Could it be sufficiently (and intentionally) disturbed in order to move to a different stable point? Alternatively, do we seek stability in information ecosystems? Is it desirable to maintain diversity? If so what is the best approach? Diversity of what? Funding streams? Creators and consumers of data? The data itself?

\subsection{Information entropy and biodiversity}

Parallel to the reductionist-integrative debate in ecology outlined in section 2.2, novel theories of information and communication emerged from work at Bell Labs and other technology firms. With the advent of digital computers during the World War II, and the subsequent interest in securely managing larger and larger sets of information, people began to speak of and study the "information environment."

One of the key problems addressed in this work was how to communicate information with systems comprised of digital transmitters, channels, and receivers. In other words, given a set of symbols that can be organized in a meaningful manner to communicate information, what is the best way for the sender to encode these symbols for transmission along a channel so that the receiver decodes the message correctly? Following this, what is the limit of information transmission on a channel? Claude Shannon $(1949 ; 1948)$ made major advances on this topic with his mathematical theory of communication, still considered canonical in computer and information science.

Shannon borrowed from physics and the study of entropy in thermodynamic systems in order to formulate a theory of entropy in the communication of information. In summary, information entropy is a measure of choice and uncertainty within a set of symbols that each have probabilities of appearing in a meaningful message. In a sense, it is a measure of the possible diversity of arrangements of the symbol set.

Ecologists picked up this idea and started to use the same methods for calculating diversity of food webs or trophic diversity (MacArthur, 1955) and later applied the idea to for the diversity of organisms themselves in an ecosystem (Margalef, 1968; 1957). Instead of symbols in an information system, ecologists calculated the entropy of organisms in an ecosystem and called it biodiversity. Margalef (1957) was "fully conscious ... of the risk of displeasing both mathematicians and biologists" applying the idea of entropy from information theory to ecosystem biodiversity. He was also aware that this mathematical model for biodiversity was far from perfect. Shannon's diversity index is still taught to students of ecology as part of a standard set of methodological tools. 
While this is an important early and direct link between information science and reductionist approaches in ecology, it leaves open several questions about diversity in information ecosystems. Do we still consider information entropy as a part of diversity in information ecosystems? Is diversity in the information ecosystem even related to information entropy as understood by Shannon? If so, what is the parallel entity in the information ecosystem that corresponds to symbols used to communicate information across a channel? Is it possible to quantify diversity in an information ecosystem?

\section{Adjacent ideas and ecological adoptions}

The above background illustrates how some concepts from ecological thinking can be borrowed or potentially transposed into the context of an information ecosystem or ecology of information (as set of relations). This paper now turns to tracing the emergence of an information ecology or the metaphor of the information ecosystem. First the adoption of ecological concepts which occurred in several different academic disciplines as "ecologies" is traced over the second half of the twentieth century (for examples, see Figure 2). An examination of some of these adoptions helps illuminate the emergence of information ecology in the late 1990s. Four examples of ecological concepts migrating into other disciplines are discussed: human and cultural ecology, cognitive ecology, media ecology, and political ecology.

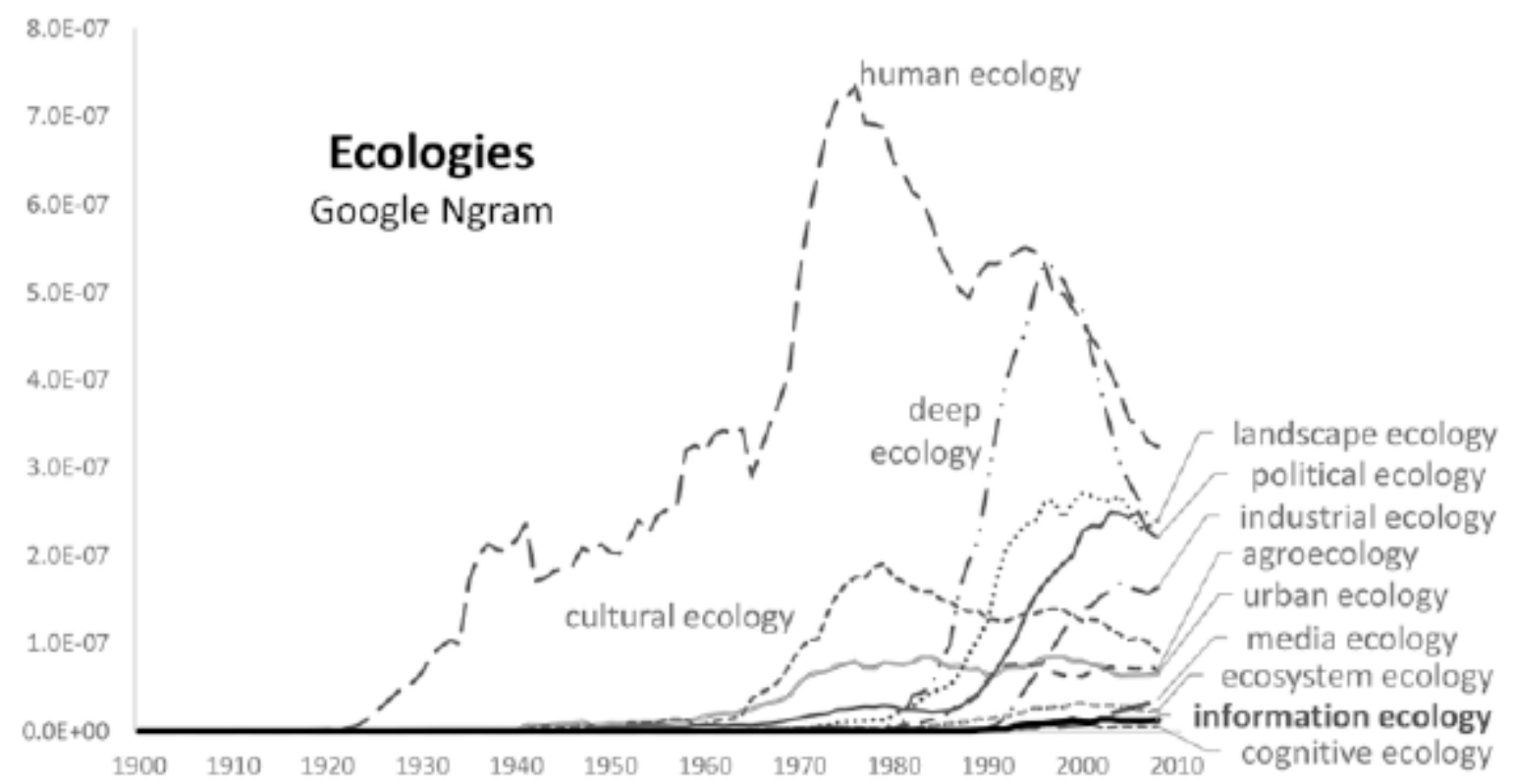


Figure 2: Emergent ecologies as a Google Ngram. Note the early dominance of human ecology and then deep ecology; only in the 1990s did ecological thinking become broadly adopted in many disciplines.

\subsection{Human and cultural ecology}

An important early bridge between ecology and information science is found in human ecology and cultural ecology of the 1960s and 1970s (both within anthropology). Similar to how ecologists measured flows of energy and nutrients during the quantitative revolution, anthropologists counted calories and food exchanges in small "closed" human societies. Cultural ecologists claimed that culturally defined norms, rules, and rituals govern homeostatic socionatural systems. The flow and management of information controlled by cultural institutions provided the feedback loops to maintain system stability. The anthropologists borrowed concepts from systems theory, cybernetics, and ecology to make their arguments.

Categorizing socio-natural systems as homeostatic and self-regulating rose in popularity through the 1960s and 1970s only to be debunked as the scale of analysis expanded (see human ecology in Figure 2). Bernard Nietschmann (1973), who studied coastal Miskito communities in Nicaragua, clearly showed that if the scale of analysis includes international trade pressures, the expansion of capitalism as an economic system, and other external factors, the stability of these "closed" systems quickly morphs into cultural and ecological degradation.

However, the idea that information is a key component of socio-natural systems remains. Information influences the formation of biosystems, the health of human beings, and our social well-being. Each one of these depend upon digital or analog systems for valuing, storing, transmitting, and receiving information. Similar to human ecology's inquiry into nature-society questions, a program of information ecology has the potential to be a synthesis between the biological sciences and the human condition through the careful study of information exchange between humans and the environment (Eryomin, 1998) [13].

A common thread in these early examples is a shared basis in the management of resources; information resources and natural resources. The emphasis on resource management was picked up in business management literature and emerged as a program of information ecology in the 1990s. Horton Forest (1978) may be the first author to have used the phrase "information ecology" in his paper on computer systems management. Kevin Harris (1989) provided one of the clearest early examples from the business management literature in his short article titled "information ecology" in which he recognized the dynamic interdependence of information systems within an organization. He analogized the interaction between systems within an organization as a type of ecosystem in the sense that they are self-regulating, progressive, and maintain states of dynamic equilibrium.

\subsection{Cognitive ecology}


In a review of cognitive ecology, Hutchins (2010) discusses the sources of the field and how it interacts with cognitive science. He wrote that "Cognitive ecology is the study of cognitive phenomena in context. Elements of cognitive ecology have been present in various corners, but not the core, of cognitive science since the birth of the field. It is now being rediscovered as cognitive science shifts from viewing cognition as a logical process to seeing it as a biological phenomenon." [14]

Hutchins contrasts logical and biological approaches to understanding cognition; early cognitive science was faced with a tension between reductionism and holism. Two schools of thought, a cybernetic and an information processing approach, emerged from the early ferment of the field. Cyberneticists, such as Gregory Bateson, emphasized the interactions between mind and the environment. Bateson (1972) entitled his theoretical manifest Steps to an ecology of mind, advocating greater attention to the interconnections between environment and the mind. On the other hand, information processing advocates concentrated on the parallels between the digital computer and the mind. The focus on the digital computer reduced the activity of the mind to symbolic event processing, relegating perceptual systems and the motor systems used to interact with the world to the periphery of the field of cognitive science. Today cognitive science is revising itself and reexamining the connections between the world and the mind through ideas originating in cognitive ecology (Hutchins, 2010).

One of the emergent themes in cognitive ecology is this contrast between the digital and the biological. Cognitive science, as a field, chose to use a digital-technological paradigm in order to manage the scope of its studies and to define the appropriate units of analysis for its research efforts. While critics of this approach were present from the beginning, their more holistic and contextual approaches were often marginalized in post-WWII funding circles. Context becomes one of the key concepts for both motivating and operationalizing a holistic shift in thinking, nevertheless. Motivating because context is key in a proper discussion of an information environment, and operationalizing because context points to the people and groups which surround and interact with any socio-technical system as a new unit of analysis.

Another emergent theme in cognitive ecology is mutual dependence. From the abstract of Hutchins review, cognitive ecology "points to the web of mutual dependence among elements of a cognitive ecosystem." (Hutchins, 2010) In Cognition in the Wild, Hutchins described the process used to navigate large Navy ships, which are excellent examples of the mutual dependence between people, technology, and information. Each component of the system, or ecology (as a set of relations), needs to be functioning well to achieve the overall goal of determining the ship's position. Mutual dependence is also a principal feature within discourses about the value of biodiversity (Hutchins, 1995). This theme is later picked up within the business management literature on information ecology.

\subsection{Media ecology}

Just as cognitive ecologists can trace back to original controversies over holism and reductionism, media ecologists can trace a similar debate in their own field of communication between qualitative and quantitative methods. Much of the early research in the field of communications tried to emulate the natural sciences and adopted quantitative methods 
borrowed from the postwar social sciences. Early studies on propaganda and other communication topics adopted a simplistic view of information transmission, which was later derided as the hypodermic or administrative model of communication. The scientistic view of communication would not be challenged until the 1960s and 1970s. Throughout this time there were researchers who approached media and communication studies from a critical point of view, including Marshall McLuhan, Walter Ong, and Neil Postman.

The network formed by McLuhan, Ong, and Postman is often cited as the foundation for media ecology studies. All three discussed the meaning of their own work and explicitly framed much of that work in environmental terms. Postman is usually credited with the earliest use of the term "media ecology" in a 1968 talk, later published in 1970. He defined media ecology as "the study of media as environments" (Strate, 2004). McLuhan described the relationship between different types of media and how they effected the mental environment.

"The medium is the message' means, in terms of the electronic age, that a totally new environment has been created. The 'content' of this new environment is the old mechanized environment of the industrial age. The new environment reprocesses the old one as radically as TV is reprocessing the film. For the 'content' of TV is the movie. TV is environmental and imperceptible, like all environments. We are aware only of the 'content' or the old environment. When machine production was new, it gradually created an environment whose content was the old environment of agrarian life and the arts and crafts. This older environment was elevated to an art form by the new mechanical environment. The machine turned Nature into an art form." [15]

Ong wrote about the "ecological concern" he believed media ecology would address, especially because "Its thrust is the dialectical opposite of the isolating thrust of writing and print." [16] He described how evolutionary thinking proposed by Darwin demonstrated the development of organisms over time through the interaction of individuals and the environment. "The new philosophical attention to openness appears not unrelated to the opening of previously isolated human groups to one another fostered by electronic communications media, telephone, radio, and ultimately television." [17]

Turning toward the environment in which communication and media interacted suggested a way to broaden the analysis of media and therefore develop a broader critique of media in society. A more contemporary definition of media ecology is

"how the form and inherent biases of communication media help create the environment or symbolic and cognitive structure in which people symbolically construct the world they come to know and understand, as well as its social, economic, political, and cultural consequences." (Lum, 2000) 
After the 1970s the study of media ecology spread in multiple directions. Ong focused on the distinction between orality and literacy, Postman became an influential public intellectual and critic of television, and McLuhan became famous in a variety of different circles thanks to the "medium is the message." Intellectual groups coalesced around many of these figures, especially in Toronto and New York, where McLuhan and Postman respectively spent much of their careers. The Media Ecology Association (http://www.media-ecology.org) was established in 1998 and solidified the use of the term media ecology.

Two themes from media ecology are worth considering when examining the adoption of ecology into different disciplines. The first is the idea of the environment. McLuhan describes how technology has created a totally new environment in which people are now embedded.

Moreover, the media and technology environment is often ignored or even imperceptible to the people who live inside of it. There is a historical evolution of communication technologies in which older environments are replaced by newer ones. The second theme is raised by Ong when he talks about the openness engendered by the work of Darwin. Before Darwin, species were considered separately from their environment, afterwards the connections between individual and environment are paramount. Technology, in the form of electronic communication devices and networks, transforms human society in an analogous way, bringing together groups which were previously isolated.

\subsection{Political ecology}

Political ecology emerged within the discipline of geography in the later decades of the twentieth century. Credit for the first use of the term is generally given to Eric Wolf (1972) discussing environmental management in the Swiss Alps. Wolf's paper explored how ownership of and access to resources structure environmental outcomes. Very generally "[ $t]$ he phrase "political ecology' combines the concerns of ecology and a broadly defined political economy. Together this encompasses the constantly shifting dialectic between society and the land-based resources, and also within classes and groups within society itself." [18]

There are at least two common uses of the term political ecology. The first defines political ecology not as a discipline but as a holistic approach to understanding the degradation of socionatural systems that gives importance to historical, political, and economic contexts. This approach provides an alternative to the standard development trope that pressure from rapidly reproducing poor populations begets degradation of the environment: instead poverty and environmental degradation are in a dialectical relationship that can spiral downwards if classbased analysis and global pressures are not considered in policy formation (Blaikie and Brookfield, 1987; Peet and Watts, 1996).

This approach also includes a critique of small scale studies from human ecology and cultural ecology, yet retains the emphasis on the governance of, and access to, natural resources in overall explanations of system dynamics. Social justice is framed as an issue of access to and control of natural resources through property rights, which then can be used as an explanatory factor for socio-natural outcomes. This leads to alternative explanations of the tragedy of the commons thesis. Instead of inevitable degradation of the common "pasture" in Hardin's (1968) example, resources owned under common property regimes and governed by local practice and 
custom are often sustainably managed. These alternate political ecological explanations that connect institutions of ownership to ecological sustainability fully acknowledge the problems of scale, complexity, and context (Ostrom, et al., 1999).

A second usage of political ecology is that of the politics of environmental science. In this usage, attention is explicitly given to science, and the knowledge, information and "raw data" that science produces, as well as its political agency in the policy arena. Social justice is described as an issue of the control of, access to, and use of the scientific information (Forsyth, 2003; Leach and Mearns, 1996). The work of Gregory Bateson was important in the development of political ecology conceived in this manner (Peet and Watts, 1996).

It is notable that there is significant overlap between both conceptions of political ecology. For example, both approaches provide alternative explanations to popular "success" stories of conquest, imperialism and colonialism in which the explanatory power of guns, disease, and metallurgical technology are primary factors ( $c f$., Diamond, 1997). Political ecologists draw attention to non-primary explanatory factors, such as the conquistadors' desire for power, wealth, and recognition. The control of the flows of both natural and information resources from core to periphery is also prominent in political ecological explanations. The "success" of the conquest and subsequent forms of imperialism was not a "natural" or "god-given" outcome depicted as geographical luck of the European societies, but instead a bloody tale of purposeful savagery and pillage.

Both usages of political ecology also draw upon narratives of ecologist as manager and the ecologist as activist. Political ecologists often seek to provide alternative solutions and policy recommendations for resource management problems through an active political engagement. In any case, political ecology has been criticized for not being political enough (Walker, 2007), as well as not being sufficiently ecological (Vayda and Walters, 1999; Walker, 2005). In a sense, political ecology fits well with Holling's (1998) observation that holistic ecological approaches tend to offer answers of limited use to real problems. At the same time, through attempts to place quantitative information on society and the environment into broader qualitative contexts, the political ecology literature provides examples for information ecology on how to use interdisciplinary approaches to make important contributions to resource governance debates at scales ranging from local to planetary.

\subsection{Ecologies and ecosystems}

What does this survey of adopting ecological thinking into other disciplines reveal? One common effect is the merger of terminologies between ecosystem and ecology. In the examples noted earlier ecosystem metaphors - the cognitive ecosystem, media ecosystem, political ecosystem - are less used than referents to various ecologies (see Figure 3). The various ecologies discussed earlier use ecological approaches to answer research questions. This might mean using tools from the ecological toolkit or even thinking broadly about relationships between the living and non-living. There is no attempt to label the system under study an ecosystem. 


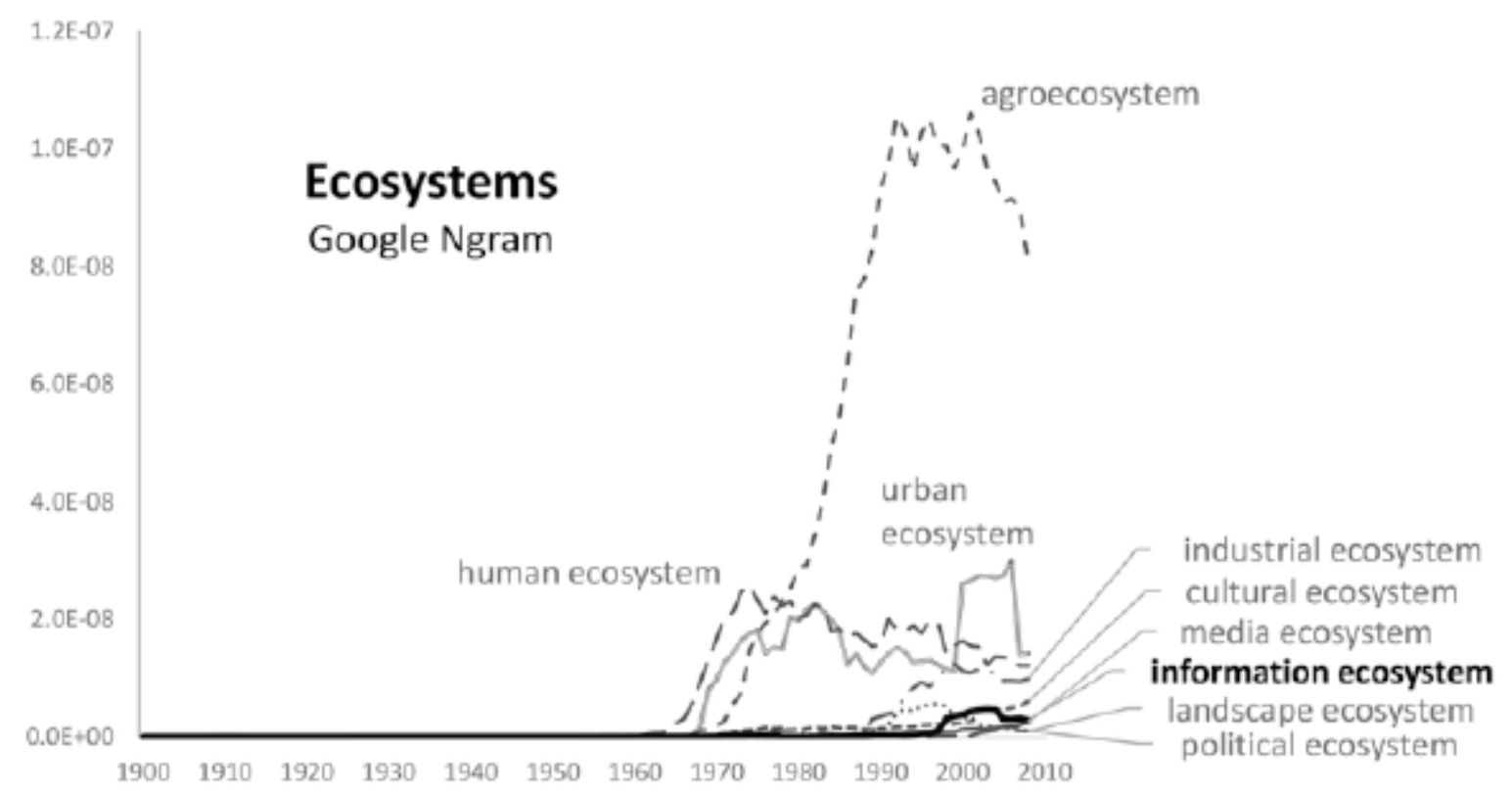

Figure 3: Emergent use varying ecosystem metaphors as a Google Ngram. Compare to Figure 2. The use of various ecologies vs. various ecosystem metaphors is an order of magnitude higher.

Other prominent themes shared across the different adoptions of ecological thinking into nonbiological disciplines include the ongoing debate between holism and reductionism, systems thinking versus complexity, and the role of technology as an agent for positive or negative change. The introduction of these ideas into new disciplines is one of the positive outcomes of the spread of ecological discourse beyond the biological origins of the concept.

\section{Two programs for information ecology}

As ecological thinking moved into popular business contexts in the 1990s, two identifiable programs of information ecology (as a set of relations, and not a field of study) were developed. The first is a managerial approach outlined as what an ecologist or a natural resource manager might call adaptive management. Davenport and Prusak (1997) suggested an "ecological" approach to information management that explicitly acknowledged the human-technology nexus. The goals for their program are focused on improving the usage of information within businesses. The second program is anthropological not managerial. It also contains a plea to re- 
incorporate people into technological solutions for data management in the corporate world, but comes from the perspective of research labs and user interface design (Nardi and O'Day, 1999).

Both narratives of information ecology draw upon cognitive ecology and emphasize a movement away from a narrow technical focus on systems for information management, which stand in for technological development, especially in the form of engineering with all of the symbolic baggage that term implies, toward a larger, contextually-dependent, vision of what information entails. Just as the cognitive ecologists wished to move away from viewing cognition as just another form of information processing, information ecologists wanted to view the organization as something greater than a computer.

\subsection{Davenport and Prusak}

Davenport and Prusak (1997) position "information ecology" as an antidote to what they call the "machine-engineering" view of technology adoption and use. Information ecology is proposed as an antidote because it "puts how people create, distribute, understand, and use information at its center" [19], instead of focusing on software design as engineers are prone to do. Business managers represent the intended audience, those involved in regular operations of organizational information systems. Davenport and Prusak argue that a holistic approach to management information systems is more effective than a systems- (in the sense of computer-based systems engineering) or engineering-based approach. The "ecological approach" behind this argument is simplistic. Ecology is basically representing any complex system with multiple parts and feedbacks between different levels; whether it is a natural or artificial makes no difference.

They define information ecology as "the science of understanding and managing whole environments" and propose four basic tenets for an information ecology approach [20]:

1. Information is not easily stored on computers - and is not "data";

2. The more complex an information model, the less useful it will be;

3. Information can take on many meanings in an organization; and,

4. Technology is only one component of the information environment and often not the right way to create change.

The role of individuals in business organizations is particularly important for Davenport and Prusak. They refuse to reduce information to data which can simply be transported around or stored by an organization using the typical tools of an IT engineer. Instead, information can have multiple meanings, different levels of complexity, and not be dependent on any particular form of technology. By describing an organization as an information ecology, Davenport and Prusak explicitly counter the machine-engineering point of view. The metaphor serves to bring people back into the world of information technology and supports one of the principal theses of the book: that technology alone cannot be a solution to data management problems. Human resources, abilities, and networks are essential for improving data management in a corporate business context. A second major thesis in their book is that novel management approaches are necessary to sustain information systems.

In chapter 3, four key components for information ecology are introduced: 
1. Integration of diverse types of information;

2. Recognition of evolutionary change;

3. Emphasis on observation and description; and,

4. Focus on people and information behavior.

The parallels between the key components of Davenport and Prusak and the adaptive management literature are quite clear, but never made explicit. Both share an emphasis on incorporating human behavior into a system and the idea of iterative or evolutionary change. In an ideal world, a business organization would adopt all of the key attributes in order to be more effective. But each attribute is also valuable in its own right, and adopting any of them will help organizations move in a more ecological direction.

In addition to describing the tenets and components of their information ecology approach, Davenport and Prusak acknowledge that any organization is embedded in multiple information environments. The internal company or organizational environment is the main focus of their argument, but any organization is also connected to other organizations, such as business partners, customers, and suppliers, as well as being involved in a larger environment of the marketplace.

The boundaries between these environments are often fuzzy and potentially quite porous. It is interesting to note that there is no mention of the natural environment as an explicit context for an organization. The import of this omission is difficult to judge. On the one hand the book is aimed at business managers who are working in technology-dominated information fields so discussing the natural environment might be considered out of scope. On the other hand, they are directly borrowing terminology from the field of ecology which takes the natural environment to be its direct subject of study. The confusion between these two impulses is part of the reason why discussing information ecology is so difficult.

\subsection{Nardi and $O^{\prime}$ Day}

Nardi and O'Day (1999) share some of the same concerns as Davenport and Prusak about the impact of technology on human living, but they approach the problem from a different disciplinary perspective. Given their background in anthropology, the focus is not on the technology but the human cultures in which technologies are embedded. Previous work in this tradition grew out of science and technology studies, as well as human computer interaction research on problems of "user resistance" to the adoption of new information systems (Star and Ruhleder, 1996; Nardi, 1993).

The critique of technology-based solutions to information problems is stated even more directly by Nardi and O'Day. They describe three different common perspectives on technology and society. The first is the tool view of technology which is very similar to the machine-engineering perspective mentioned by Davenport and Prusak. The tool viewpoint sees information technologies as just devices used by organizations to accomplish tasks. Tools can be improved through better design and integration but are morally neutral. The second view is of technology as a text which can be interpreted by scholars in order to discern intentions and meaning behind 
using a particular technology. The third view, and the one to which they devote most of their discussion, is the systems view.

The systems view is one of the strongest critiques of technology-based solutions to information problems. Propounded by Jacques Ellul (1964) and Langdon Winner (1977), among others, the systems view argues that human lives are conditioned, perhaps even determined, by technologies that surround them. Winner critiques three common myths about technology: that it is neutral; that people have control over the technologies used by society; and, that people understand the implications of the technology that they use [21]. The fact that many technologies lead to unintended consequences is prima facie evidence against the last two myths.

Nardi and O’Day listed several key ideas from ecology which they applied to information:

1. Systemic relationships between the parts of an ecology;

2. Diversity of people and tools in an information system;

3. Co-evolution between the people and the tools in the information ecosystem; and,

4. Keystone species, or mediators who "build bridges across institutional boundaries and translate across disciplines." [22]

5. Locality, or the name (meaning) and habitation (location in the network/system) of a technology.

Of great significance to their concept of "library ecosystems" is their notion of keystone species. Indeed, they name librarians at Apple and Xerox as the keystone species in their particular corporate information ecologies (as sets of relationships) [23]. Certainly this makes librarians feel important, but it also raises questions as to whether individual humans can really be a keystone species in any ecosystem (see above). The information ecosystem certainly needs humans to be sustained, but this is not true of ecosystems comprised of living communities, natural environs, and relationships between the two.

The key point made by Nardi and O'Day is that, although they are sympathetic to the systems critique of technology, they believe this critique is too totalizing and thus a deterrent to intervention. This idea is encapsulated in the slogan "rhetoric of inevitability" which they argue is too often part of the discussions around the effects of technology. The idea of an information ecology is offered as an explicit alternative to the systems critique of information and technology. They contrast the term "ecology" to "communities", arguing that the latter is too homogenous and the former implies greater diversity. Ecology also draws out the importance of continual evolution and change, an implication that is lacking for a notion of "community."

An information ecology (set of relations), according to Nardi and O'Day, offers an opportunity for local action which is not dependent on the larger, systemic critiques of technology. Following a systemic critique of technology, as described by Ellul or Winner, is likely to lead to a sense of despair and powerlessness of individuals to affect technologies used by society. Instead we should speak of engagement and participation, especially in the specific local situations in which each of us encounters any given technology. By acting where we have power, in the local habitations where the meaning of a technology is being created, we can influence information 
ecologies around us. The rhetoric of ecology brings out the holistic relationships between people and tools, and points us to a local arena where we can stimulate change.

\section{Critique of the "information ecosystem"}

Information ecosystems and information ecologies share much more than the root of the word ecology. Information ecology outlines a program for research that borrows ecological concepts and applies them to the domain of information science. The metaphor of the "information ecosystem" connotes notions of evolution, connectivity, diversity, complexity, dynamic equilibriums, keystone species, and even predator-prey relationships. So far we have explored how these concepts have emerged both in ecology as a discipline and in several "ecological" approaches in other fields. This cross fertilization has been very productive in terms of generating new knowledge about these phenomena, both natural (ecology) and social (information science).

There are several positive outcomes from the interplay between ecology and information science. The reminders that technical solutions are embedded in social contexts found in the work of Nardi and Davenport are timely and important (see also Lucas, et al., 2012). This resonates with the contextual focus on political economy in political ecology literature. The broad focus on interdisciplinary management of resources, both natural and digital, deserves further attention. Mathematical models of diversity, cybernetic theory, dynamic equilibriums, and chaotic systems with tipping points continue to produce novel insights and inform methods in adaptive management. Moreover, the idea that everything is connected and somehow interdependent is very powerful — but perhaps does not provide actionable observations.

The negative outcomes must also be engaged. Unfortunately, the role that data and information play as a conduit between social phenomena and the natural world tends to be lost in the information ecosystem metaphor. Based on this observation, four criticisms of the "information ecosystem" are made in this section of the paper. First, the naturalizing of human communities through the metaphor of the information ecosystem in a scholarly context is problematic.

Second, information or data itself become a naturalized part of the environment. Third, an information ecology may lead to greenwashing of the information economy. Fourth, the natural environment fades into invisibility with the rhetoric of information ecosystems. An underlying "information ethic" binds these four critiques which will be explored in greater detail in this paper. The critique concludes with a discussion of useful ways forward to investigate and contribute to the sustainable management of our information systems, be they "data assemblages," "digitally constructed memories," or "cross-domain knowledge bases."

\subsection{Human communities are not ecosystems}

One of the uses of the ecosystem metaphor in research data management and scholarly communication circles is that scholarly communities are like "ecosystems" through which rivers 
of data flow (Choudury, 2010). The metaphor invokes a very appealing image of librarians and information specialists tending flows of data which pass through scholarly ecosystems, nestled within the green hills of the academy. There are two problems with this metaphor. First, librarians are alluded to as a keystone species, albeit not explicitly. Second, it is also a dangerously comforting image that borderlines on committing the naturalistic fallacy; because things are found in nature, they are good [24]. Steven Pinker (2002) counters this fallacy by noting that possible logical conclusions include statements such as, "if birds and beasts engage in adultery, infanticide, and cannibalism, it must be OK." [25]

Another use of the metaphor is that the library itself is an ecosystem in which information specialists, library users, and library professionals interact as different species who have both "competing interests" and relations of "mutual benefit." These relationships lead to a coevolution of the "species" in rapidly changing research, publishing, and technology environments (Walter, 2008). At a broader scale, some authors suggest that even human economies should be thought of as ecologies (as a set of relations) [26]. Once again this evokes a sort of informal image where mutualism and cooperation inevitably lead to some sort of outcome that benefits all the "species" involved.

Scholarly communities, be it the research community or library community, are hierarchical, much like a government agency, with politics and power rippling through their ranks. We can broaden the metaphor and suggest that the U.S. Department of Defense, or any other government agency, is an information ecosystem through which data flows naturally. A powerful critique of this line of thought comes from Richard Stallman: "It is inadvisable to describe the free software community, or any human community, as an 'ecosystem,' because that word implies the absence of ethical judgment." Stallman continues:

“The term 'ecosystem' implicitly suggests an attitude of nonjudgmental observation: don't ask how [sic] what should happen, just study and understand what does happen. In an ecosystem, some organisms consume other organisms. In ecology, we do not ask whether it is right for an owl to eat a mouse or for a mouse to eat a seed, we only observe that they do so. Species' populations grow or shrink according to the conditions; this is neither right nor wrong, merely an ecological phenomenon, even if it goes so far as the extinction of a species.

By contrast, beings that adopt an ethical stance toward their surroundings can decide to preserve things that, without their intervention, might vanish — such as civil society, democracy, human rights, peace, public health, a stable climate, clean air and water, endangered species, traditional arts ... and computer users' freedom." [27]

These observations were written within the context of communities engaged in the development of digital information systems. Although the ecosystem metaphor may be convenient and perhaps even practical to describe a scholarly community, we should be careful with expressing 
the implicit lack of morality in the world of information. In this critique, the information ethic is based on explicitly acknowledging our human morality in communities that manage information resources, paying close attention to who wins and loses in these communities.

\subsection{Data is not natural}

An ecosystem or ecology (as a set of relations) is an abstraction of nature and the relationships between living organisms and their surrounding non-living environment. While living organisms, including humans, have a two-way relationship with ecosystems - organisms influence the ecosystem and the ecosystem influences organisms - an ecosystem is not purposefully made by organisms for material exchange. On the other hand, we know that markets are purposefully built for economic exchange. We can only wonder if nature was constructed with such purpose (see Glacken, 1967). To reduce an ecosystem to the human-made, such as an information ecosystem, denies possibilities of spiritualism and non-quantifiable relationships that are found in nature.

In Lucas, et al. (2012), there is an allusion that the rules of the Internet that were created to manage complexity are analogous to the rules of nature in an ecosystem. While the authors admit that if we are "to play god by creating an ecology ... the first requirement ... is humility", the assumption that we create, instead of manage, ecosystems is controversial [28]. Is there the possibility of the emergence of artificial life in an information ecosystem? Does linking emergence to biological and environmental concepts benefit our understanding of novel information systems? With the information ecosystem metaphor, do we suggest that we have finally reached the status of a deity and created new forms of life? Furthermore, this allusion naturalizes the Internet in the sense that the rules are not open to change by the common user, or indeed anyone else. Only the appropriate Internet deities have the privileges to modify these rules.

If the rules of the Internet are natural, does this imply that data found on the Internet is natural? The National Centre for Research Methods defined big data is defined as "'naturally occurring', high-volume digital data which are often available in 'real-time' and which are not produced with social scientific research as an objective." [29] Or as noted by Perry Rotella in Forbes: "The real impetus is the potential insights we can derive from this new, vast, and growing natural resource." [30] (Rotella, 2012, emphasis ours). Within these statements it is completely obviated that we collect data from natural and social environments; it is not given to us as a natural phenomenon, but something we choose to gather, interpret, and use to make sense of the environment (Kitchin, 2014).

Within certain critical academic circles naturalizing a phenomenon that is a human creation somehow perceiving the social phenomena as natural - is considered dangerous. A good example might be an explanation of the conquest of Peru as inevitable and 'natural' because of superior European weaponry and the disease trajectory from Europe to South America (to simplify a famous argument). Nowhere in this explanation is the conquistadors' lust for gold, their penchant for violence, and disrespect of life emphasized as another factor in the conquest ( $c f$. . Galeano, 1973; de las Casas, 1992). We must question whether the emotional analysis of Twitter data represents the human condition, or if the market analytics of Amazon purchases 
represent a natural phenomenon, especially if you consider that a human-created commercial economy drives these interactions.

The information ethic underlying this critique is based on explicitly acknowledging the choices humans make in the collection, analysis, and management of data. These choices necessarily affect not only how we perceive social and natural phenomena, but they shape the institutions that we create, such as markets, to manage information. Indeed, we should perhaps better heed the words of Mordechai Haklay (2013): all code has "social, ethical, moral, and environmental implications." [31] His call to explicitly acknowledge ethical decisions in the digital world directly applies to systems of information and how they are used.

\subsection{Green[wash]ing the information economy}

It is difficult to argue that anything ecological is wrong or bad. Using the term "information ecology" (as a set of relations) may imply that information systems form part of "everything" good. Lucas, et al. (2012) made a strong argument that the purpose of using the information ecology metaphor (as a set of relations) is to bring individuals back into the solution. The authors focus on human-centric design with less visible technologies. Their arguments are politically conservative for the 'liberation' of information from regulation; the information ecology (as a set of relations) will be self-regulating, based in free-market neoliberalism, and generate profit opportunities for businesses.

The description of the early development of ecological thought in the first part of this paper showed how closely the discourse of markets and environment could be aligned to a discussion of ecology. The early mirroring between the economy and ecosystem was supplanted by later ideas incorporating complex systems, cooperation, and autopoesis. In their view of ecosystems, Lucas, et al. (2012) harkened back to the some of the earliest uses of the term "ecosystem" a usage that many ecologists have now dismissed. Perhaps Lucas, et al. used the word ecology, instead of economy, because they knew that with the word economy, the artificiality of the system would be revealed to readers and the inevitable naturalization of the system that they described would be that much more difficult.

The danger of using the language of information ecosystems and ecologies is that very real environmental impacts of information economies will be less visible. As an example, the "cloud" is anything but a cloud. It is literally tons of digital storage devices (spinning metal disks) residing in air-conditioned complexes with thick steel walls and concrete encasings, consuming enormous amounts of energy [32]. All the equipment on which our information technologies depend draw significant quantities of natural resources from the environment (metal, plastic, energy, and rare earth minerals), eventually becoming part of a waste stream returning to the environment. In many parts of the world, extraction and recycling are unregulated industries with negative environmental and social impacts [33]. The cloud relies on these very material industries. How long will it be until negative environmental outcomes of high-flow liberated data will become apparent?

The information ethic in this critique is based upon explicitly acknowledging that information systems are human creations, not natural phenomena. It follows the same argument that the free 
market is a myth; better said, the so-called "invisible hand" of Adam Smith is subordinate to institutions created by humans [34]. This does not deny the possibility of creating greener and friendlier information systems; instead it creates opportunities to emphasize the human role in these processes.

\subsection{Disappearing nature}

There is a confusion of ecology with ecosystems, and both with economies ( $c f$. , Lucas, et al., 2012; Nardi and O'Day, 1999). Similar to ecosystems, economies draw material wealth from nature: stocks and flows of natural resources, minerals, water, and energy. But in classical economics, it is often forgotten that resource streams and waste flows take place within an ecosystem. From the perspective of ecological economics, the economy is entirely dependent on nature and indeed is a human-created subsystem of natural processes (see Figure 4).

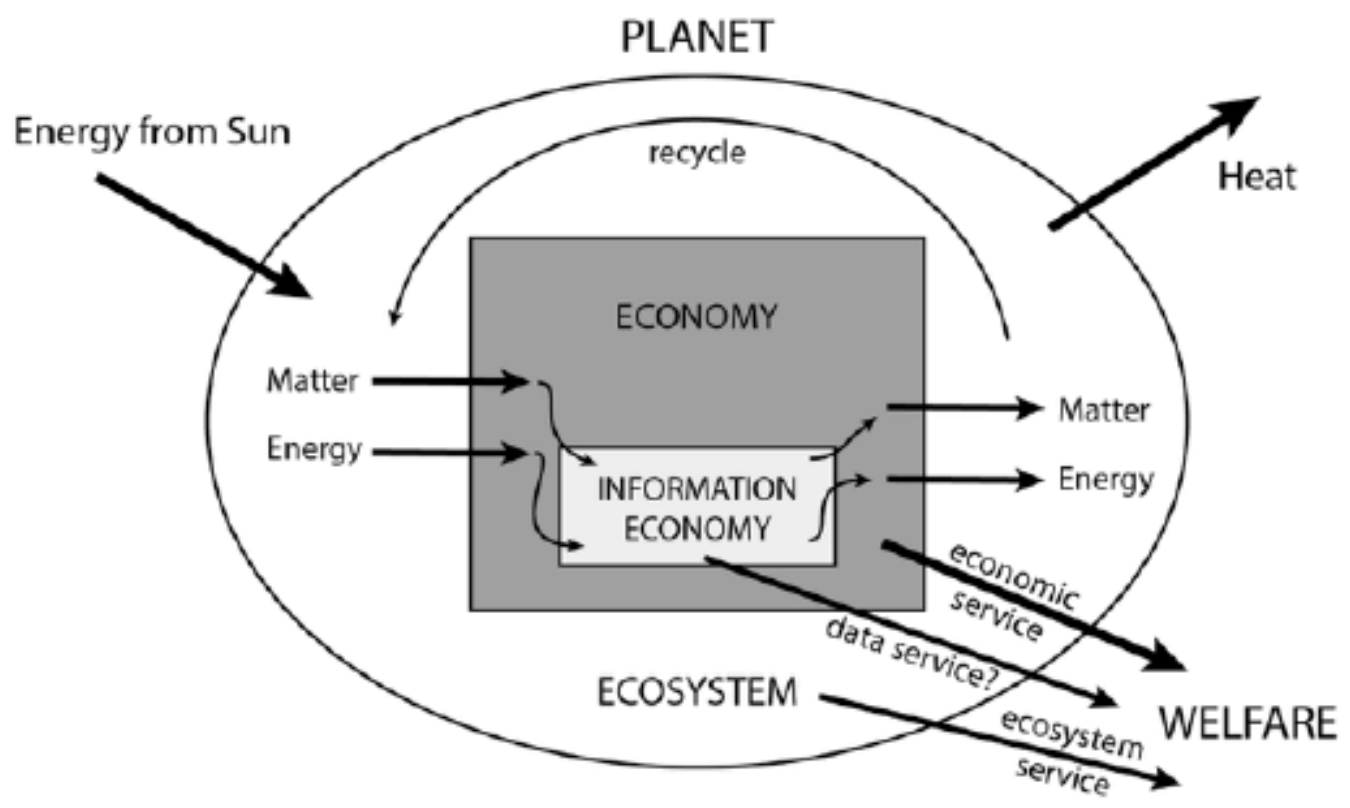

Figure 4: The information economy understood as a sector of the global economy which itself is a sub-system of the global ecosystem [35].

Through the claim that the information system is an ecology (as a set of relations) instead of an economy (a human-created institution of exchange), natural ecosystems become even less visible. The very real need for natural resources such as energy, metal, petroleum, and space itself to build and maintain information systems fade into the background of the conversation. 
Our review of the literature suggests the possibility that the use of the term "information ecosystem" or "information ecology" (as the relations) further disconnects us from our natural environment. This disconnection may indeed be the most pressing problem that human society currently faces. As we become less connected to ecosystems across scales from local to global, the more likely it is that we will destroy what sustains us (Worthy, 2013).

Opposed to this tendency to make nature less visible, ecological economics places all human economic activity within the bounds of the global ecosystem (see Figure 4). If the information economy always grows, where will it fit in the future (the outer circle cannot grow)? One of the enduring problems in libraries is physical space to store books. Will this be the same for digital objects? Some argue that storage technology will continue to pack more information onto smaller and smaller devices. Indeed, Kryder's law states that digital storage media costs drop exponentially, and have for the last thirty years [36]. Is there a limit to this expansion ( $c f$., Rosenthal, et al., 2012)? Do we need to recognize that information storage as an economic activity takes place within a bounded physical system? Or is this question some novel form of digital Malthusian thinking?

The information ethic in this critique is similar to that of Leopold's land ethic. We can extend the information ethic described earlier to include the broader non-human community in our consideration of morality in the systems of information that we build. This can include the explicit consideration of both the living and non-living, other than human actors as we construct and govern information systems.

\subsection{Sustainable resource management}

A common thread in all of the literature reviewed is that of resource management, either digital or natural resources. This thread provides insight into how to sustainably manage the complex and diverse systems of information that we build. From the information ecology literature, we see an emphasis on context, particularly political and economic, for the best management of data within an organization. This resonates particularly well with the literature from political ecology and its efforts to contribute to sustainability studies with the allied fields in geography on land use change and socio-ecological systems. Management prescriptions from this work emphasize adaptive management cycles, where assessment leads to planning and action, followed by evaluation and a return to assessment (Holling, 1978; Liu, et al., 2007). Attention to system disturbance and potential shifts from dynamic equilibriums to periods of chaotic behavior is an another parallel between the adaptive management literature and the information ecology programs, as outlined by Nardi, Davenport, and others.

This shared interest in sustainable resource management merits further attention. Several leading scholars have made progress in linking natural resource management with the management of information resources, largely through thinking about forms of property and ownership. Elinor Ostrom, who examined as a scholar the sustainable management of natural resources, turned her focus at the end of her career to information resources, in conjunction with Charlotte Hess (Hess and Ostrom, 2007). Their work on ownership regimes and sustainable management is a powerful argument for the importance of common property resources in sustainable systems, even in a time where private property tends to be the mainstream prescription. She argued against Hardin's 
(1968) "tragedy of the commons," whereby common property regimes beget environmental degradation.

James Boyle tackled the same problem from the perspective of intellectual property rights and the management of material in the public domain. He argued against the assumption behind copyright that implied that "words can be overgrazed" and therefore required the protection of private property. Instead, he demonstrated that the public domain is more important than ever in a digital age [37]. By raising concerns over increasing corporate ownership of scholarly output, Boyle asked if copyright was also applicable to data. "Overgrazing" of data seemed unlikely, implying that balanced public/private ownership of data would be key for sustainable data management ( $c f ., \mathrm{Yu}, 2005)$.

Joseph Stiglitz (1999) also acknowledged the need for balanced ownership regimes because over-emphasis on copyright and private ownership of information could damage knowledge exchange, a global public good. While not drawing directly from ecological literature, the shared focus on ownership regimes and resource management in Ostrom, Boyle, and Stiglitz parallels thinking from political ecology. This points to an opportunity for future work to address issues of sustainability, justice, and politics in information systems through research on the role of humancreated ownership institutions, both public and private, in sustainable resource governance.

As data becomes increasingly liberated and flows more freely in a growing information economy, our ability to capture larger and larger quantities of data also increases. At the same time, does the quality of captured data decline? As Neil Postman suggested, "We have transformed information [and data] into a form of garbage." [38] Does this potential decline in quality information somehow hamper effective decision-making or are we able to filter and analyze the data in ways that provide novel insights that improve effective decision-making? If this is true and mess makers do not make claims to their digital garbage, does this mean we should start talking of information externalities, much like environmental economists speak of environmental externalities? The information externality would be the cost borne by society that low-quality information incurs. This possibility deserves more attention.

\section{Conclusions}

The "information ecosystem" metaphor is a powerful way to understand complexes of data, people, and machines in a rapidly changing social and technological environment. At first glance, it may suggest an interest in nature because of the presence of the eco- prefix and its common use as a term in the biological and environmental sciences. There is also a holistic implication that an ecosystem encompasses or contains the natural functions of a system. It is at this point when the concept of nature arises in our thoughts that the usage of the word "ecosystem" can become confusing. The suggested presence of nature makes an ecosystem into a natural object, and this objectification makes the connection between an ecosystem and nature seem inevitable. 
When applied to human-built systems, such as an economy, this implication of naturalism imbued in the very term being used begins to confuse the actual system under analysis. The problem with this confusion is that the very reason for using the word "ecosystem" in the first place, in order to emphasize the importance of nature and the non-human environment, is subtly eliminated from the conversation. Nature disappears, and we are left with a human-built system, many times an economy, which may pay no more attention to the impacts of human activity on the environment as any other system that we might have wished to condemn.

Consider the use of phrase "information ecology" in the work of Davenport and Prusak. They approach the issue as business management scholars trying to improve human management processes for information within business organizations. From the beginning, this is a human problem which only connects to nature at a most banal level. Humans are part of nature, but that does not mean that everything human is natural. This contrast is very difficult to explain clearly and applying "ecosystem" or "ecology" to human organizations adds to the confusion.

Value judgments are made by the very use of the word "nature." To be natural is to be spontaneous, without processing or bias. But human organizations are artificial in the most basic sense. They are produced by humans and maintained by human ingenuity and skill. They do not arise spontaneously. Their organization is determined by rules, behavior, and hierarchies of human actions. In a sense, they are fundamentally non-natural; instead they are cultural. To call these systems artificial is not derogatory, or at least it should not be considered as such. We should take pride in the artificial organizations that we have created, because they have accomplished some of the most complex tasks humans are capable of, from forming governments to sending probes into space.

Acknowledging that these systems are artificial does not mean that the systems are in any way separated from nature. If ecology has taught us anything it is that humans are deeply embedded in the natural world. Our organizations, systems, and vast quantities of information are artificial because we have built them. They are much more like autopoietic machines, like a complicated steam engine with a speed governor to limit the risks of explosion, rather than an organism imbued with life that adopts both cooperative and competitive strategies to reproduce. This incredible system of communication and data sharing is built inside of an ecosystem which includes humans, all other forms of life, and non-living materials upon which we rely. Instead of referring to every collection of parts found in human civilization as an ecosystem, we can simply refer to what they are, artificial systems or economies which have been built by humans for a specific purposes.

Prepending the word information to ecosystems does nothing to clarify the matter because the word information is almost as difficult to define as nature. But there are many other uses of the word "ecosystem" that can be abandoned more quickly. When a newspaper article refers to a "music ecosystem" we should just ascribe that usage to laziness. What is really being referred to is a music economy or the music business, the complex of artificial organizations, individuals, and technology which humans have built to produce, distribute, and enjoy music.

When applying ecology or ecosystem to technology and information the same laziness is never far away. Phrases like "big data ecosystem" or "scholarly ecosystem" are more accurately 
referring to the economic, business, and technological structures which support these human activities. As the title of this paper suggests, information has long been recognized as a part of the ecosystem. Information broadly conceived is what mediates relationships between living organisms and their non-living environment. While metaphors may be a useful way to understand novel phenomena, their forms and roles within learning processes are still under debate. Like Bohr's planetary model of the atom, some metaphors are destined for retirement as our understanding of phenomena deepens. Perhaps it is time to retire the information ecosystem metaphor as we begin to better understand the data revolution. $\mathbf{F m}$

\section{About the authors}

Timothy Norris is a library assistant professor in research data science Libraries and the Center for Computational Science at the University of Miami. Prior to this appointment he was a CLIR postdoctoral fellow in data curation at the University of Miami Libraries. He holds a Ph.D. in environmental studies (a.k.a., geography) from the University of California Santa Cruz (UCSC). Before entering the academy, he started and maintained a small development NGO in Peru. E-mail: tnorris [at] miami [dot] edu

Todd Suomela is a digital pedagogy specialist at Bucknell Univeristy. Prior to this position he was a CLIR a postdoctoral fellow in data curation at the University of Alberta. He earned a Ph.D. in communication and information from the University of Tennessee, and a master's degree in information science from the University of Michigan.

E-mail: contact [at] toddsuomela [dot] com

\section{Acknowledgements}

We would like to thank the entire 2014-2016 cohort of Council for Library and Information Resources (CLIR) - Digital Library Federation (DLF) postdoctoral fellows without which this conversation would have never started. Special thanks goes to Dr. Elliott Shore and Dr. Lauren Coates for the encouragement to continue with this project. The usual disclaimers apply.

\section{Notes}

1. Aristotle, Poetics, Section 1459a, at http://catalog.perseus.org, accessed 19 August 2017.

2. For example, see Walter (2008) and Muccie, et al. (2016). Sometimes alternate metaphors are used such as the "publishing ecosystem" or the "research ecosystem" (for respective examples, see Esposito, 2013; Dylla, 2016).

3. boyd, 2016, personal communication. 
4. Palmer and Kraushaar, 2013, p. 288.

5. Odum, 1971, p. 3. For a good history of ecological thinking, see Glacken (1967). In this magisterial work, Glacken explores historical thinking on three principal questions: What is nature's influence on man? What is man's influence on nature? Is there a grand purpose in these relationships?

6. The Tennyson poem — "In Memoriam A.H.H." — originally refers to human relationships! From Canto 56:

Who trusted God was love indeed

And love Creation's final law

Tho' Nature, red in tooth and claw

With ravine, shriek'd against his creed

7. See a definition of lebensraum in the Holocaust Encyclopedia at https://www.ushmm.org/wlc/en/article.php?ModuleId=10008219, accessed 19 August 2017.

8. Holling, 1998, p. 3 .

9. Cantlon in Barbour, 1995, p. 241.

10. Leopold, 1949, p. 204.

11. While ecologists have discarded this theory and environmental managers are struggling to adopt theories of dynamic equilibriums, the evolved ecosystem theory appears live and well in the technology literature which speaks of "mature ecosystems." See https://gradle.org/ under the title "Automate Everything" in which they speak of "mature ecosystems of plugins," accessed 17 July 2017.

12. Ecosystem modeling was then a very new field that used computers to model species populations in a study ecosystem.

13. This recurring theme appears as a recent extension of the adaptive management and Panarchy literatures (Eddy, et al., 2014).

14. Hutchins, 2010, p. 705.

15. McLuhan, 1994, p. 13.

16. Ong 1977, p. 324, in Strate, 2004.

17. Ibid.

18. Blaikie and Brookfield, 1987, p. 17.

19. Davenport and Prusak, 1997, chapter 1. 
20. Ibid.

21. Nardi and O’Day, 1999, chapter 4.

22. Nardi and O’Day, 1999, p. 53.

23. See the op-ed which appeared in a number of U.S. newspapers, "Put a good librarian, not software, in driver's seat." An example can be found in the Las Vegas Sun (3 June 1996), at https://lasvegassun.com/news/1996/jun/03/nardi-oday-valauskas-put-a-good-librarian-not-soft/, accessed 22 August 2017.

24. For a similar example in business management, see Lucas, et al., 2012, p. 68.

25. From a Pinker interview (30 October 2002) at

http://www.upi.com/Odd_News/2002/10/30/QA-Steven-Pinker-of-Blank-

Slate/26021035991232/, accessed 22 August 2017.

26. Lucas, et al., 2012, p. 72.

27. Free Software Foundation, 2017. "Words to avoid (or use with care) because they are loaded or confusing," at https://www.gnu.org/philosophy/words-to-avoid.en.html, accessed 22 August 2017.

28. Lucas, et al., 2012, p. 140.

29. "National Centre for Research Methods call for Methodological Research Projects," p. 4, at http://www.esrc.ac.uk/files/funding/funding-opportunities/ncrm/ncrm-methodological-researchprojects-call-specification-pdf/, accessed 22 August 2017.

30. Perry Rotella, 2012. "Is data the new oil?" Forbes (2 April), at https://www.forbes.com/sites/perryrotella/2012/04/02/is-data-the-new-oil/, accessed 22 August 2017.

31. Haklay, 2013, p. 60.

32. "Worldwide, the digital warehouses use about 30 billion watts of electricity ..."; see James Glanz, 2012. "Power, pollution and the Internet," New York Times (22 September), at http://www.nytimes.com/2012/09/23/technology/data-centers-waste-vast-amounts-of-energybelying-industry-image.html, accessed 22 August 2017.

33. See, for example, Richard Wray, 2008. "Breeding toxins from dead PCs," Guardian (6 May), at https://www.theguardian.com/environment/2008/may/06/waste.pollution, accessed 22 August 2017. 
34. On the mythology of the "invisible hand," see Jonathan Schlefer, 2012. "There is no invisible hand," Harvard Business Review (10 April), at https://hbr.org/2012/04/there-is-no-invisiblehand, accessed 22 August 2017.

35. Adapted from Daly and Farley, 2004, p. 18.

36. Chip Walter, 2005. "Kryder's Law," Scientific American (1 August), at https://www.scientificamerican.com/article/kryders-law/, accessed 22 August 2017.

37. Boyle, 2003, footnote 15, on p. 5 .

38. Postman in Stepp, 1999, p. 50. The exact quote is: "Where information was once an essential resource in helping us to gain control over our physical and symbolic worlds, our technological ingenuity transformed information into a form of garbage, and ourselves into garbage collectors." See Neil Postman, 1997. "Science and the story that we need," First Things (January), at https://www.firstthings.com/article/1997/01/science-and-the-story-that-we-need, accessed 22 August 2017.

\section{References}

David Abram, 1991. "The mechanical and the organic: On the impact of metaphor on science," In: Stephen H. Schneider and Penelope J. Boston (editors). Scientists on Gaia. Cambridge Mass.: MIT Press, pp. 66-74.

Chris Anderson, 2016. "TED's secret to great public speaking," at http://www.ted.com/talks/chris_anderson_teds_secret_to_great_public_speaking\#t-383633, accessed 22 August 2017.

Aristotle, Poetics, at http://catalog.perseus.org, accessed 19 August 2017.

Karen S. Baker and Geoffrey C. Bowker, 2007. "Information ecology: Open system environment for data, memories, and knowing," Journal of Intelligent Information Systems, volume 29, number 1, pp. 127-144.

doi: https://doi.org/10.1007/s10844-006-0035-7, accessed 22 August 2017.

Michael G. Barbour, 1995. "Ecological fragmentation in the fifties," In: William Cronon (editor). Uncommon ground: Toward reinventing nature. New York: Norton, pp. 233-255.

Gregory Bateson, 1972. Steps to an ecology of mind: Collected essays in anthropology, psychiatry, evolution, and epistemology. San Francisco: Chandler.

Firket Berkes, Johan Colding, and Carl Folke, 2000. "Rediscovery of traditional ecological knowledge as adaptive management," Ecological Applications, volume 10, number 5, pp. 1,2511,262 . 
Piers Blaikie and Harold Brookfield, 1987. Land degradation and society London: Methuen.

danah boyd, 2016. "RE: the ecosystem of prediction," personal communication.

James Boyle, 2003. "Foreword: The opposite of property," Law and Contemporary Problems, volume 66, pp. 1-32, and at http://scholarship.law.duke.edu/lcp/vol66/iss1/1, accessed 22 August 2017.

Rachael Carson, 1962. Silent spring. Boston: Houghton Mifflin.

Bartolomé de las Casas, 1992. The devastation of the Indies: A brief account. Translated by Herma Briffault. Baltimore, Md.: Johns Hopkins University Press.

Sayeed Choudury, 2010. "Data curation: An ecological perspective," College \& Research Libraries News, volume 71, number 4, pp. 194-196.

doi: https://doi.org/10.5860/crln.71.4.8354, accessed 22 August 2017.

Frederic E. Clements, 1936. "Nature and structure of the climax," Journal of Ecology, volume 24, number 1, pp. 252-284. doi: https://doi.org/10.2307/2256278, accessed 22 August 2017.

Barry Commoner, 1971. The closing circle: Nature, man, and technology. New York: Knopf.

Joseph H. Connell, 1978. "Diversity in tropical rain forests and coral reefs," Science (24 March), volume 199, number 4335, pp. 1,302-1,310.

doi: https://doi.org/0.1126/science.199.4335.1302, accessed 22 August 2017.

Herman E. Daly and Joshua Farley, 2004. Ecological economics: Principles and applications. Washington, D.C.: Island Press.

Thomas H. Davenport with Laurence Prusak, 1997. Information ecology: Mastering the information and knowledge environment. New York: Oxford University Press.

Jared Diamond, 1997. Guns, germs, and steel: The fates of human societies. New York: Norton.

Fred Dylla, 2016. "Three years after the OSTP public access directive: A progress report," Scholarly Kitchen (8 March), at https://scholarlykitchen.sspnet.org/2016/03/08/guest-post-freddylla-three-years-after-the-ostp-public-access-directive-a-progress-report/, accessed 22 August 2017.

Brian G. Eddy, Brian Hearn, Joan E. Luther, Michael van Zyll de Jong, Wade Bowers, Reg Parsons, Douglas Piercey, Guy Strickland, and Barry Wheeler, 2014. "An information ecology approach to science: Policy integration in adaptive management of social-ecological systems," Ecology and Society, volume 19, number 3, at https://www.ecologyandsociety.org/vol19/iss3/art40/, accessed 22 August 2017. doi: http://dx.doi.org/10.5751/ES-06752-190340, accessed 22 August 2017. 
Paul Ehrlich, 1968. The population bomb. New York: Ballantine Books.

Jacques Ellul, 1964. The technological society. Translated by John Wilkinson. New York: Knopf.

Alexei L. Eryomin, 1998. "Information ecology — A viewpoint," International Journal of Environmental Studies, volume 54, numbers 3-4, pp. 241-253.

doi: http://dx.doi.org/10.1080/00207239808711157, accessed 22 August 2017.

Joseph Esposito, 2013. “A new publishing ecosystem emerges,” Scholarly Kitchen (23 January), at https://scholarlykitchen.sspnet.org/2013/01/23/a-new-publishing-ecosystem-emerges/, accessed 12 February 2016.

Horton W. Forest, 1978. "Information ecology," Journal of Systems Management, volume 29, number 9, pp. 22-36.

Tim Forsyth, 2003. Critical political ecology: The politics of environmental science. London: Routledge.

Free Software Foundation, 2017. "Words to avoid (or use with care) because they are loaded or confusing," at https://www.gnu.org/philosophy/words-to-avoid.en.html, accessed 22 August 2017.

Eduardo Galeano, 1973. Open veins of Latin America: Five centuries of the pillage of a continent. Translated by Cedric Belfrage. New York: Monthly Review Press.

Clarence J. Glacken, 1967. Traces on the Rhodian Shore: Nature and culture in Western thought from ancient times to the end of the eighteenth century. Berkeley: University of California Press.

James Glanz, 2012. "Power, pollution and the Internet," New York Times (22 September), at http://www.nytimes.com/2012/09/23/technology/data-centers-waste-vast-amounts-of-energybelying-industry-image.html, accessed 22 August 2017.

H.A. Gleason, 1939. "The individualistic concept of the plant association," American Midland Naturalist, volume 21, number 1, pp. 92-110.

doi: http://dx.doi.org/10.2307/2420377, accessed 22 August 2017.

Daniel Goodman, 1975. "The theory of diversity-stability relationships in ecology," Quarterly Review of Biology, volume 50, number 3, pp. 237-266.

doi: http://dx.doi.org/10.1086/408563, accessed 22 August 2017.

Lance H. Gunderson and C.S. Holling (editors), 2002. Panarchy: Understanding transformations in human and natural systems. Washington, D.C.: Island Press. 
Ernst Haeckel, 1866. Generelle morphologie der organismen: Allgemeine grundzüge der organischen formen-wissenschaft, mechanisch begründet durch die von Charles Darwin reformirte descendenz-theorie. Berlin: G. Reimer.

Joel B. Hagen, 1992. An entangled bank: The origins of ecosystem ecology. New Brunswick, N.J.: Rutgers University Press.

Mordechai Haklay, 2013. "Neogeography and the delusion of democratisation," Environment and Planning A, volume 45, number 1, pp. 55-69.

doi: https://doi.org/10.1068/a45184, accessed 22 August 2017.

Garrett Hardin, 1968. "The tragedy of the commons," Science, volume 162, number 3859 (13 December), pp. 1,243-1,248.

doi: https://doi.org/10.1126/science.162.3859.1243, accessed 22 August 2017.

K. Harris, 1989. “Information ecology," International Journal of Information Management, volume 9, number 4, pp. 289-290.

doi: https://doi.org/10.1016/0268-4012(89)90052-2, accessed 22 August 2017.

Charlotte Hess and Elinor Ostrom (editor), 2007. Understanding knowledge as a commons: From theory to practice. Cambridge, Mass.: MIT Press.

C.S. Holling, 1998. "Two cultures of ecology," Conservation Ecology, volume 2, number 2, article 4, at http://www.consecol.org/vol2/iss2/art4/, accessed 22 August 2017.

C.S. Holling (editor), 1978. Adaptive environmental assessment and management. New York: Wiley.

C.S. Holling, 1973. "Resilience and stability of ecological systems," Annual Review of Ecology and Systematics, volume 4, pp. 1-23.

doi: https://doi.org/10.1146/annurev.es.04.110173.000245, accessed 22 August 2017.

Edwin Hutchins, 2010. "Cognitive ecology," Topics in Cognitive Science, volume 2, number 4, pp. 705-715.

doi: https://doi.org/10.1111/j.1756-8765.2010.01089.x, accessed 22 August 2017.

Edwin Hutchins, 1995. Cognition in the wild. Cambridge, Mass.: MIT Press.

Rob Kitchin, 2014. The data revolution: Big data, open data, data infrastructures \& their consequences. Los Angeles, Calif.: Sage.

Petr Kropotkin, 1987. Mutual aid: A factor of evolution. London: Freedom Press.

Melissa Leach and Robin Mearns (editors), 1996. The lie of the land: Challenging received wisdom on the African environment. Oxford: International African Institute in assocation with James Currey. 
A.S. Leopold, S.A. Cain, C.M. Cottam, I.N. Gabrielson, and T.L. Kimball, 1963. "Wildlife management in the national parks: The Leopold report" (4 March), at http://www.craterlakeinstitute.com/online-library/leopold-report/complete.htm, accessed 22 August 2017.

Aldo Leopold, 1949. A Sand County almanac, and sketches here and there. New York: Oxford University Press.

Diana Liverman, 2004. "Who governs, at what scale and at what price? Geography, environmental governance, and the commodification of nature," Annals of the Association of American Geographers, volume 94, number 4, pp. 734-738.

David N. Livingstone and Richard T. Harrison, 1981. "Meaning through metaphor: Analogy as epistemology," Annals of the Association of American Geographers, volume 71, number 1, pp. 95-107. doi: https://doi.org/10.1111/j.1467-8306.1981.tb01343.x, accessed 22 August 2017.

James E. Lovelock and Lynn Margulis, 1974. "Atmospheric homeostasis by and for the biosphere: The Gaia hypothesis," Tellus, volume 26, numbers 1-2, pp. 2-10. doi: https://doi.org/10.1111/j.2153-3490.1974.tb01946.x, accessed 22 August 2017.

Peter Lucas, Joe Ballay, and Mickey McManus, 2012. Trillions: Thriving in the emerging information ecology. Hoboken, N.J.: Wiley.

Casey Man Kong Lum, 2000. "Introduction: The intellectual roots of media ecology," New Jersey Journal of Communication, volume 8, number 1, pp. 1-7. doi: http://dx.doi.org/10.1080/15456870009367375, accessed 22 August 2017.

Robert MacArthur, 1955. "Fluctuations of animal populations and a measure of community stability," Ecology, volume 36, number 3, pp. 533-536.

Ramón Margalef, 1968. Perspectives in ecological theory. Chicago: University of Chicago Press.

Ramón Margalef, 1957. "La teora de la información en ecologa," Memorias de la Real Academia de Ciencias y Artes Barcelona, volume 23, pp. 373-449.

Robert M. May, 1974. "Biological populations with non-overlapping generations: Stable points, stable cycles, and chaos," Science, volume 186, number 4164 (15 November), pp. 645-647. doi: http://dx.doi.org/10.1126/science.186.4164.6455, accessed 22 August 2017.

Marshall McLuhan, 1994. Understanding media: The extensions of man. Cambridge, Mass.: MIT Press.

Donella H. Meadows, Dennis L. Meadows, Jørgen Randers, and William W. Behrens III, 1972. The limits to growth: A report for the Club of Rome's project on the predicament of mankind. New York: Universe Books. 
A.M. Merenlender, L. Huntsinger, G. Guthey, and S.K. Fairfax, 2004. "Land trusts and conservation easements: Who is conserving what for whom?" Conservation Biology, volume 18, number 1, pp. 65-76.

doi: http://dx.doi.org/10.1111/j.1523-1739.2004.00401.x, accessed 22 August 2017.

Mary Rose Muccie, Joe Lucia, Elliott Shore, Clifford Lynch, and Peter Berkery, 2016. “Across the great divide: Findings and possibilities for action from the 2016 summit meeting of academic libraries and university presses with administrative relationships (P2L)," Association of Research Libraries, at http://www.arl.org/storage/documents/across-the-great-divide-2016-p21summit.pdf, accessed 22 August 2017.

Bonnie Nardi, 1993. A small matter of programming: Perspectives on end user computing. Cambridge, Mass.: MIT Press.

Bonnie Nardi and Vicki O’Day, 1999. Information ecologies: Using technology with heart. Cambridge Mass.: MIT Press.

National Centre for Research Methods, n.d. "National Centre for Research Methods call for Methodological Research Projects," at http://www.esrc.ac.uk/files/funding/fundingopportunities/ncrm/ncrm-methodological-research-projects-call-specification-pdf/, accessed 22 August 2017.

Bernard Nietschmann, 1973. Between land and water: The subsistence ecology of the Miskito indians, Eastern Nicaragua. New York: Seminar Press.

Timothy Norris, 2014. "Morality in information ecosystems" (18 September), at http://connect.clir.org/blogs/tim-norris/2014/09/18/morality-in-information-ecosystems, accessed 22 August 2017.

Bethany Nowviskie, 2014. "Johannes Factotum \& the ends of expertise" (3 November), at http://nowviskie.org/2014/johannes-factotum/, accessed 22 August 2017.

Eugene P. Odum, 1971. Fundamentals of ecology. Third edition. Philadelphia: Saunders.

Walter J. Ong, 1977. Interfaces of the word: Studies in the evolution of consciousness and culture. Ithaca, N.Y.: Cornell University Press.

Elinor Ostrom, Joanna Burger, Christopher B. Field, Richard B. Norgaard, and David Policansky, 1999. "Revisiting the commons: Local lessons, global challenges," Science, volume 284, number 5412 (9 April), pp. 278-282.

doi: http://dx.doi.org/10.1126/science.284.5412.278, accessed 22 August 2017.

Oxford English Dictionary, 2008. “ecology, n.," at http://www.oed.com, accessed 22 August 2017. 
Mark H. Palmer and Scoot Kraushaar, 2013. "Volunteered geographic information, actornetwork theory, and severe storm reports," In: Daniel Sui, Sarah Elwood, and Michael Goodchild (editors). Crowdsourcing geographic knowledge: Volunteered geographic information (VGI) in theory and practice. Dordrecht: Springer, pp. 287-306. doi: https://doi.org/10.1007/978-94-007-4587-2_16, accessed 22 August 2017.

Richard Peet and Michael Watts (editors), 1996. Liberation ecologies: Environment, development, social movements. New York: Routledge.

Steven Pinker, 2002. "Q\&A: Steven Pinker on 'Blank Slate'” (30 October), at http://www.upi.com/Odd_News/2002/10/30/QA-Steven-Pinker-of-BlankSlate/26021035991232/, accessed 22 August 2017.

Neil Postman, 1997. "Science and the story that we need," First Things (January), at https://www.firstthings.com/article/1997/01/science-and-the-story-that-we-need, accessed 22 August 2017.

S.R. Ranganathan, 1931. The five laws of library science. Madras: Madras Library Association.

David S.H. Rosenthal, Daniel Rosenthal, Ethan L. Miller, Ian Adams, Mark W. Storer, and Erez Zadok, 2012. "The economics of long-term digital storage," at http://www.unesco.org/new/fileadmin/MULTIMEDIA/HQ/CI/CI/pdf/mow/VC_Rosenthal_et_al _27_B_1330.pdf, accessed 22 August 2017.

Perry Rotella, 2012. "Is data the new oil?" Forbes (2 April), at https://www.forbes.com/sites/perryrotella/2012/04/02/is-data-the-new-oil/, accessed 22 August 2017.

Jonathan Schlefer, 2012. "There is no invisible hand," Harvard Business Review (10 April), at https://hbr.org/2012/04/there-is-no-invisible-hand, accessed 22 August 2017.

Claude E. Shannon, 1949. The mathematical theory of communication. Urbana: University of Illinois Press.

Claude E. Shannon, 1948. “A mathematical theory of communication,” Bell Systems Technical Journal, volume 27, number 3, pp. 379-423, 623-656.

doi: http://dx.doi.org/10.1002/j.1538-7305.1948.tb01338.x, accessed 22 August 2017.

Susan Leigh Star and Karen Ruhleder, 1996. "Steps toward and ecology of infrastructure: Design and access for large information spaces," Information Systems Research, volume 7, number 1, pp. 111-134. doi: https://doi.org/10.1287/isre.7.1.111, accessed 22 August 2017.

John R. Stepp, 1999. "Prospectus for information ecology," Journal of Ecological Anthropology, volume 3, number 1, at http://scholarcommons.usf.edu/jea/vol3/iss 1/4/, accessed 22 August 
2017.

doi: http://dx.doi.org/10.5038/2162-4593.3.1.4, accessed 22 August 2017.

Joseph Stiglitz, 1999. "Knowledge as a global public good," In: Inge Kaul, Isabelle Grunberg, and Marc A. Stern (editors). Global public goods: International cooperation in the 21st century. New York: Oxford University Press, pp. 308-325. doi: http://dx.doi.org/10.1093/0195130529.003.0015, accessed 22 August 2017.

D.R. Stoddart, 1966. "Darwin's impact on geography," Annals of the Association of American Geographers, volume 56, number 4, pp. 683-698. doi: http://dx.doi.org/10.1111/j.1467-8306.1966.tb00585.x, accessed 22 August 2017.

Lance Strate, 2004. "A media ecology review," Communication Research Trends, volume 23, number 2, pp. 1-48, and at http://cscc.scu.edu/trends/v23/v23_2.pdf, accessed 9 February 2016.

A.G. Tansley, 1935. "The use and abuse of vegetational concepts and terms," Ecology, volume 16, number 3, pp. 284-307.

doi: http://dx.doi.org/10.2307/1930070, accessed 22 August 2017.

Alfred Tennyson, 1849. "In Memoriam A.H.H.," at

https://en.wikisource.org/wiki/In_Memoriam_A._H._H., accessed 22 August 2017.

David Tilman and John A. Downing, 1994. "Biodiversity and stability in grasslands," Nature, volume 367, number 6461 (27 January), pp. 363-365.

doi: http://dx.doi.org/10.1038/367363a0, accessed 22 August 2017.

Andrew P. Vayda and Bradley B. Walters, 1999. "Against political ecology," Human Ecology, volume 27, number 1, pp. 167-179.

doi: http://dx.doi.org/10.1023/A:1018713502547, accessed 22 August 2017.

Chip Walter, 2005. “Kryder's Law," Scientific American (1 August), at

https://www.scientificamerican.com/article/kryders-law/, accessed 22 August 2017.

Peter A. Walker, 2007. "Political ecology: Where is the politics?" Progress in Human Geography, volume 31, number 3, pp. 363-369.

doi: http://dx.doi.org/10.1177/0309132507077086, accessed 22 August 2017.

Peter A. Walker, 2005. "Political ecology: Where is the ecology?" Progress in Human Geography, volume 29, number 1, pp. 73-82.

doi: http://dx.doi.org/10.1191/0309132505ph530pr, accessed 22 August 2017.

Scott Walter, 2008. “The library as ecosystem," Library Journal (1 October), at http://lj.libraryjournal.com/2008/10/academic-libraries/the-library-as-ecosystem/, accessed 22 August 2017. 
Langdon Winner, 1977. Autonomous technology: Technics-out-of-control as a theme in political thought. Cambridge, Mass.: MIT Press.

Eric Wolf, 1972. “Ownership and political ecology,” Anthropological Quarterly, volume 45, number 3, pp. 201-205.

Donald Worster, 1994. Nature's economy: A history of ecological ideas. Second edition. New York: Cambridge University Press.

Kenneth Worthy, 2013. Invisible nature: Healing the destructive divide between people and the environment. Amherst, N.Y.: Prometheus Books.

Richard Wray, 2008. "Breeding toxins from dead PCs," Guardian (6 May), at https://www.theguardian.com/environment/2008/may/06/waste.pollution, accessed 22 August 2017.

Peter K. Yu, 2005. "Intellectual property and the information ecosystem," Michigan State Law Review, volume 2005, number 1, pp. 1-20.

\section{Editorial history}

Received 1 August 2016; revised 18 August 2017; accepted 22 August 2017.

(c) (7) (8)

This paper is licensed under a Creative Commons Attribution-NonCommercial 4.0 International License.

Information in the ecosystem: Against the "information ecosystem" by Timothy B. Norris and Todd Suomela.

First Monday, Volume 22, Number 9 - 4 September 2017 https://firstmonday.org/ojs/index.php/fm/article/download/6847/6530

doi: http://dx.doi.org/10.5210/fm.v22i19.6847 